\title{
Effect of different feed ingredients on digestive enzymes activity and on the histology of liver and intestine in Labeo rohita Hamilton, 1822
}

\author{
K. JAVED IQBAL ${ }^{1}$, MUHAMMAD ASHRAF ${ }^{2}$, ARSHAD JAVID ${ }^{2}$, M. S. CHAUDHRY ${ }^{1}$, \\ NOOR KHAN $^{2}$, HAMID MAJEED ${ }^{3,5}$, FARZANA ABBAS ${ }^{2}$, M. HAFEEZ-UR-REHMAN ${ }^{2}$, \\ FAYYAZ RASOOL ${ }^{2}$, MUHAMMAD ALTAF ${ }^{4}$ AND IRFAN ${ }^{5}$ \\ ${ }^{1}$ The Islamia University of Bahawalpur, Pakistan \\ ${ }^{2}$ University of Veterinary and Animal Sciences, Lahore, Pakistan \\ ${ }^{3}$ Government College University, Lahore, Pakistan \\ ${ }^{4}$ Women University Azad Jammu and Kashmir Bagh, Pakistan \\ ${ }^{5}$ Cholistan University of Veterinary and Animal Sciences, Bahawalpur, Pakistan \\ e-mail: khalid.javed@iub.edu.pk
}

\section{ABSTRACT}

Present study compared the effect of fishmeal and selected plant-origin feed ingredients on digestive enzymes activity as well as on the histology of liver and intestine in Labeo rohita. Guar meal (GM), soybean meal (SBM), cotton seed meal $(\mathrm{CSM})$ and canola meal $(\mathrm{CM})$ were used as experimental feed ingredients in the four treatment diets, while fishmeal (FM) incorporated diet served as control. There were three replicates for each of the treatment and control diets. The experiment was conducted in 15 fiber glass tanks, each having 10 fish. Fish in each tank was fed @ 4\% of body weight. Protease activity varied significantly $(\mathrm{p}<0.05)$ between anterior and posterior part of the intestine while amylase and lipase activities of whole intestine differed significantly $(\mathrm{p}<0.05)$ between the treatments. Maximum lipase activity was observed in fish fed with GM while minimum with CM ingredients. Vacuolation of hepatocytes and some variations in the mid intestine were also observed in response to different feed ingredients. Protease activity was greater throughout the intestinal tract when fish were fed with CSM and FM diets. Results of the present study indicated that CSM and FM are better ingredients for feed formulation for L. rohita.

Keywords: Amylase, Cotton seed meal, Digestive enzymes, Fishmeal, Histology, Intestine, Lipase, Liver, Protease

\section{Introduction}

In developing countries, fish is one of the best sources of animal protein as it provides about $26 \%$ of the daily protein requirement (Delgado et al., 2002; Louka et al., 2004). Labeo rohita Hamilton, 1822 is one of the prime freshwater fish species, commercially important in Asia in general and in Indian subcontinent in particular (Khan et al., 2004). In aquaculture, nutrition is the basic field where lots of work have been undertaken and there is further scope for future research (Eroldogan et al., 2004; Gomez-Requeni et al., 2004; Eroldogan et al., 2006a, b) because regional differences in the ingredients make diet formulations difficult. Better feed consumption improves fish growth as it implies better enzymatic activities which is greatly influenced by the feeding habits of fishes (Smith, 1980; Lundstedt et al., 2002). For understanding feed digestion mechanism and adaptation to the change in nutritional environment in fish, it is necessary to study the digestive enzymes and their activities in different parts of the intestine (Francis et al., 2001; Sunde et al., 2004; Romarheim et al., 2007; Santigosa et al., 2008). Study of the digestive enzymes is a reliable tool to understand digestive processes and fish nutritional status (Harms et al., 1991; Johnston et al., 2004). Proteolytic and amylase enzymes' activities can unveil the ability of different fish species to use protein and carbohydrates (Hidalgo et al., 1999). Lipases are also inducible enzymes (Aliyu-Paiko et al., 2010) and can be stimulated by the dietary lipid content (Buchet et al., 2000; Li et al., 2012). A positive correlation between lipase activity and dietary lipid content in juvenile rice field eel (Monopterus albus) has been documented (Ma, 2014). In fish it will be easy to understand the nutrient digestibility after understanding enzymatic activity (Kolkovski, 2001) and it will facilitate better feed formulations (El-Sayed et al., 2000; Eusebio and Coloso, 2002). The histological changes in liver and intestine are also associated with nature of feed ingredients 
(Caballero et al., 2004; Uran et al., 2009; Poleksic et al., 2007). In fish, replacement of fishmeal (FM) with plant origin feed proteins causes reduced growth rates and pathological changes, mainly enteritis in the distal part of the intestine (Uran et al., 2009). Present experiment was therefore planned to understand the effect of different plant origin feed ingredients in comparison with fish meal, on digestive enzymes activity as well as on the histological features of liver and intestine in juvenile L. rohita.

\section{Materials and methods}

This study was conducted in the Department of Fisheries and Aquaculture, University of Veterinary and Animal Sciences, Ravi Campus Pattoki, Lahore, Pakistan. Experiments were conducted in fiberglass tanks $(12.5 \times 4.5 \times 3.0$ feet, length $\times$ width $\times$ depth $)$ using juvenile Labeo rohita.

\section{Experimental design}

Experiments were designed following completely randomised design (CRD). Fifteen uniform-sized fiber glass tanks were stocked with 10 nos. each of juvenile L. rohita having body weight ranging from 80 to $120 \mathrm{~g}$. Four experimental diets incorporated with plant origin feed ingredients viz., soybean meal (SBM), cotton seed meal (CSM), canola meal (CM) and guar meal (GM) were formulated along with a control diet containing fish meal (FM). Fish were regularly fed with the experimental diets in three replicates tanks each, @ 4\% of wet body weight, twice a day for three months (90 days).

\section{Proximate analysis}

Feed ingredients were analysed for fat, moisture, protein, fiber, ash and phosphorus by Buchi NIR
Technology (Buchi NIRFlex N-500) (Table I) (Martinez et al., 2003; Iqbal et al., 2015). The ingredients were dried, ground and were placed in sampler cups. The cups were placed in NIR machine for 2 min which then displayed a complete proximate analysis report.

\section{Mineral analysis}

Well ground sample $(0.5 \mathrm{~g})$ was taken in a conical flask, $10 \mathrm{ml}$ of $\mathrm{HNO}_{3}$ was added, the mixture was then boiled for $15 \mathrm{~min}$ at $60^{\circ} \mathrm{C}$ and then $5 \mathrm{ml}$ perchloric acid was added. It was boiled again for another $15 \mathrm{~min}$ at $60^{\circ} \mathrm{C}$. The flask was then placed on a hot plate and heated until sample volume reduced to $1 \mathrm{ml}$. This sample was diluted to $100 \mathrm{ml}$ by addition of distilled water. Sodium ( $\mathrm{Na}$ ) and potassium $(\mathrm{K})$ were measured through flame photometric method while calcium $(\mathrm{Ca})$, iron $(\mathrm{Fe})$, zinc $(\mathrm{Zn})$, copper $(\mathrm{Cu})$ and magnesium $(\mathrm{Mg})$ were determined in an atomic absorption spectrophotometer (AAS) (Iqbal et al., 2014).

\section{Sample preparation for intestinal enzymes}

Six fish samples each from experiment and control diets (three for whole intestine and three each for anterior and posterior portions of the intestine) were collected. These samples were degutted, removed intestine and homogenised in a homogeniser by adding chilled Tris- $\mathrm{HCl}$. The homogenate was centrifuged at $6000 \mathrm{~g}$ at $4^{\circ} \mathrm{C}$ for $15 \mathrm{~min}$ and the supernatant was collected and stored at $-20^{\circ} \mathrm{C}$ (Ismat et al., 2013) until analyses of intestinal enzymes activity (amylase, protease and lipase).

Amylase activity

To estimate amylase activity, the sample homogenate along with $1 \%$ starch solution and phosphate buffer (pH 6.9) were added in the sample test tubes in the ratio

Table 1. Proximate composition of feed ingredients

\begin{tabular}{llllll}
\hline Parameter & Fishmeal & Cotton seed meal & Canola meal & Guar meal & Soybean meal \\
\hline Fat (\%) & $8.76 \pm 0.02$ & $0.55 \pm 0.07$ & $0.88 \pm 0.05$ & $2.51 \pm 0.06$ & ND \\
Moisture (\%) & $6.06 \pm 0.08$ & $8.59 \pm 0.09$ & $8.49 \pm 0.07$ & $5.56 \pm 0.07$ & $10.66 \pm 0.06$ \\
Protein (\%) & $40.96 \pm 0.07$ & $41.37 \pm 0.08$ & $39.64 \pm 0.06$ & $33.8 \pm 0.05$ & $35.40 \pm 0.07$ \\
Fiber (\%) & $1.49 \pm 0.07$ & $7.39 \pm 0.06$ & $8.17 \pm 0.06$ & $8.66 \pm 0.07$ & $13.58 \pm 0.07$ \\
Ash (\%) & $25.37 \pm 0.06$ & $13.99 \pm 0.06$ & $5.74 \pm 0.04$ & $10.61 \pm 0.08$ & $10.88 \pm 0.04$ \\
Phosphorus (\%) & ND & $0.64 \pm 0.06$ & $0.96 \pm 0.035$ & $0.61 \pm 0.04$ & ND \\
Ca (ppm) & $0.565 \pm 0.04$ & $1.155 \pm 0.05$ & $1.170 \pm 0.07$ & $1.195 \pm 0.06$ & $3.970 \pm 0.28$ \\
$\mathrm{Mg}(\mathrm{ppm})$ & $2.135 \pm 0.08$ & $1.450 \pm 0.07$ & $1.695 \pm 0.04$ & $2.615 \pm 0.07$ & $2.210 \pm 0.03$ \\
$\mathrm{Na}(\mathrm{ppm})$ & $48.000 \pm 0.14$ & $4.550 \pm 0.07$ & $5.250 \pm 1.49$ & $5.400 \pm 1.27$ & $3.400 \pm 0.57$ \\
$\mathrm{~K}(\mathrm{ppm})$ & $68.950 \pm 1.63$ & $84.550 \pm 2.76$ & $71.200 \pm 12.16$ & $76.950 \pm 11.81$ & $106.500 \pm 6.36$ \\
$\mathrm{Fe}(\mathrm{ppm})$ & $3.410 \pm 0.11$ & $4.245 \pm 0.11$ & $2.900 \pm 0.09$ & $3.295 \pm 0.12$ & $7.950 \pm 0.51$ \\
$\mathrm{Zn}(\mathrm{ppm})$ & $0.265 \pm 0.02$ & $0.350 \pm 0.04$ & $0.275 \pm 0.04$ & $0.180 \pm 0.04$ & $0.270 \pm 0.04$ \\
$\mathrm{Cu}(\mathrm{ppm})$ & $0.065 \pm 0.02$ & $0.085 \pm 0.01$ & $0.045 \pm 0.01$ & $0.075 \pm 0.01$ & $0.130 \pm 0.01$ \\
\hline
\end{tabular}

$\mathrm{ND}=$ Not detected 
of 1:1:1. Starch solution $(1 \mathrm{ml})$ was added in the blank test tube and both sample and blank tubes were incubated at $37^{\circ} \mathrm{C}$ for $15 \mathrm{~min}$. One milliliter of glucose solution $(0.1 \%)$ was taken as standard in a test tube. Subsequently, $1 \mathrm{ml}$ DNS (3,5-dinitrosalicylic acid) reagent was added to the sample, blank and standard test tubes and all the test tubes were kept in boiling water bath for $1 \mathrm{~min}$. These test tubes were then cooled at room temperature and then $2 \mathrm{ml}$ distilled water was added in standard and blank test tubes. Absorbance of blank, standard and samples were measured in a spectrophotometer at $540 \mathrm{~nm}$ and activity of amylase (units $\mathrm{ml}^{-1} \mathrm{~min}^{-1}$ ) was estimated as per Ismat et al. (2013).

\section{Protease activity}

Protease enzyme activity was assessed using $1 \%$ azocasein in $50 \mathrm{~mm}$ Tris- $\mathrm{HCl}$ having $\mathrm{pH} 7.5$ (Garcia-Carreno 1992). Ten microliter of homogenate was mixed with $0.5 \mathrm{ml}$ of phosphate buffer $(\mathrm{pH} 7.5)$, $0.5 \mathrm{ml}$ of substrate solution and incubated for $10 \mathrm{~min}$ at $37^{\circ} \mathrm{C}$. The reaction was stopped by adding $0.5 \mathrm{ml}$ of $20 \%$ trichloro-acetic acid (TCA) and then centrifuged for $5 \mathrm{~min}$ at $14,000 \mathrm{~g}$. Absorbance of the supernatant was measured at $366 \mathrm{~nm}$. Standard curve was prepared using different concentrations $(0,2,4,5,6,8$ and $10 \mathrm{mg})$ of azocasein (Ismat et al., 2013).

\section{Lipase activity}

One milliiter of sample was stirred in the presence of $3.5 \mathrm{ml}$ phosphate buffer $(\mathrm{pH} 7.5)$ and $0.5 \mathrm{ml}$ olive oil for $30 \mathrm{~min}$ at $37^{\circ} \mathrm{C}$. Enzyme activity was stopped by adding $1 \mathrm{ml}$ of acetic acid and then 3-4 drops of phenolphthalein indicator was added in the mixture. Then mixture was titrated against $\mathrm{NaOH}(10 \mathrm{~mm})$ solution till the colour became pink (Ismat et al., 2013).

Lipase activity (units $\left.\mathrm{ml}^{-1} \mathrm{~min}^{-1}\right)=\begin{aligned} & \begin{array}{l}\text { Vol. of } \mathrm{NaOH} \times \text { Normality of } \\ \mathrm{NaOH} \times 1000 \times 40 \times 1000\end{array} \\ & \begin{array}{l}\text { Vol. of sample homogenate used } \\ \times 1000 \times \text { mol. wt. of oleic acid } \mathrm{x} \\ \text { time }(\mathrm{min}) \text { of incubation }\end{array}\end{aligned}$

\section{Histology}

On termination of the experimental trial, liver and mid intestine samples were collected from three fish per treatment for histological analyses. These samples were immediately fixed in 10\% neutral buffered formalin and processed following standard histological procedures i.e., dehydrated in ascending series of ethanol concentrations, and embedded in paraffin. Tissue sections were cut at
4-5 $\mu \mathrm{m}$, stained with hematoxylin and eosin (Humason, 1979; Markovic et al., 2012).

\section{Physico-chemical parameters of water}

The water quality parameters viz., dissolved oxygen (DO) was determined using DO meter (YSI 55 Incorporated, Yellow Springs, Ohio, 4387, USA), pH using pH meter (LT-Lutron pH-207 Taiwan) while electrical conductivity, water temperature, salinity and total dissolved solids (TDS) were determined using conductivity meter (Condi 330i WTW 82362 Weilheim, Germany) following APHA (1998).

The data obtained were subjected to statistical analyses using the software package SAS 9.1 and analysis of variance (ANOVA) was applied to compare means.

\section{Results and discussions}

Water quality parameters (temperature, dissolved oxygen, $\mathrm{pH}$, TDS, salinity and electrical conductivity) remained within the permissible limits and corroborated with previous findings (Ali et al., 2000; Abid and Ahmed, 2009).

During the present study, maximum protease activity was observed in fish fed with CSM while CM fed fish showed maximum amylase activity. Fernandez et al. (2001) stated that the constituents of feed work as driving force for digestive enzymes in fish. Differences $(p \leq 0.05)$ in protease activity were observed in various parts of the intestine and that of the whole intestine. Amylase activity also showed significant differences in whole intestine of fish fed on different feed ingredients (Table 2). Kumar et al. (2011) documented significant differences in amylase and protease activity in Labeo rohita in response to different feed ingredients. Similar effects were observed in Pagrus pagrus (Suzer et al., 2007) and in juvenile Senegalese sole (Rodiles et al., 2012) when fishmeal was partially replaced by plant protein sources. Findings of all these investigations are in line with our findings and confirm that variations in dietary quality as well quantity do have lot of bearings on enzymatic activities of digestive tract.

Due to physiological versatility in $L$. rohita fingerlings, higher lipase secretions were observed for lipid digestion (Sethuramalingam and Haniffa, 2002). During the present study, lipase activity in anterior, posterior and whole intestine was found variable $(\mathrm{p}<0.05)$ for all the five feed ingredients (Table 3 ). Lipases are inducible enzymes which could be stimulated by the dietary lipid content (Aliyu-Paiko et al., 2010; Li et al., 2012). Maximum 
Table 2. Effect of feed ingredients on the amylase and protease enzyme activities of different intestinal parts of Labeo rohita

\begin{tabular}{|c|c|c|c|c|c|c|}
\hline \multirow{2}{*}{ Feed ingredient } & \multicolumn{3}{|c|}{ Amylase $\left(\mathrm{U} \mathrm{ml}^{-1} \mathrm{~min}^{-1}\right)$} & \multicolumn{3}{|c|}{ Protease $\left(\mathrm{U} \mathrm{ml}^{-1} \mathrm{~min}^{-1}\right)$} \\
\hline & Anterior intestine & Posterior intestine & Whole intestine & Anterior intestine & Posterior intestine & Whole intestine \\
\hline $\mathrm{CM}$ & $0.053^{\mathrm{d}} \pm 0.05$ & $0.045^{\mathrm{d}} \pm 0.02$ & $0.355^{\mathrm{a}} \pm 0.06$ & $0.911^{\mathrm{f}} \pm 0.15$ & $2.240^{\mathrm{e}} \pm 0.18$ & $3.945^{\mathrm{abc}} \pm 0.09$ \\
\hline CSM & $0.044^{\mathrm{d}} \pm 0.02$ & $0.060^{\mathrm{d}} \pm 0.03$ & $0.178^{\mathrm{bcd}} \pm 0.08$ & $3.386^{\mathrm{cd}} \pm 0.69$ & $4.043^{\mathrm{abc}} \pm 0.08$ & $4.431^{\mathrm{a}} \pm 0.01$ \\
\hline FM & $0.121^{\mathrm{d}} \pm 0.06$ & $0.105^{\mathrm{d}} \pm 0.03$ & $0.144^{\mathrm{cd}} \pm 0.06$ & $0.713^{\mathrm{f}} \pm 0.11$ & $3.912^{\mathrm{abc}} \pm 0.49$ & $4.129^{\mathrm{ab}} \pm 0.59$ \\
\hline GM & $0.156^{\mathrm{bcd}} \pm 0.09$ & $0.111^{\mathrm{d}} \pm 0.05$ & $0.313^{\mathrm{ab}} \pm 0.03$ & $2.203^{\mathrm{e}} \pm 0.07$ & $3.057^{\mathrm{d}} \pm 0.23$ & $3.367^{\mathrm{cd}} \pm 0.12$ \\
\hline SBM & $0.122^{\mathrm{d}} \pm 0.07$ & $0.036^{\mathrm{d}} \pm 0.01$ & $0.302^{\mathrm{abc}} \pm 0.03$ & $3.936^{\mathrm{bcd}} \pm 0.03$ & $3.896^{\mathrm{abc}} \pm 0.01$ & $3.936^{\mathrm{abc}} \pm 0.05$ \\
\hline
\end{tabular}

$\mathrm{CM}=$ Canola meal, $\mathrm{CSM}=$ Cotton seed meal, $\mathrm{FM}=$ Fishmeal, $\mathrm{GM}=$ Guar meal, $\mathrm{SBM}=$ Soybean meal

Table 3. Effect of different feed ingredients on lipase activity (IU ml-1 $\left.\mathrm{min}^{-1}\right)$ of different intestinal parts of Labeo rohita

\begin{tabular}{llll}
\hline Feed ingredient & Anterior intestine & Posterior intestine & Whole intestine \\
\hline CM & $2.431 \pm 0.09^{\mathrm{f}}$ & $4.087 \pm 0.58^{\mathrm{ef}}$ & $8.455 \pm 0.29^{\mathrm{d}}$ \\
CSM & $9.618 \pm 0.87^{\mathrm{d}}$ & $13.612 \pm 0.69^{\mathrm{c}}$ & $9.550 \pm 0.64^{\mathrm{c}}$ \\
FM & $4.599 \pm 0.57^{\mathrm{ef}}$ & $10.082 \pm 0.15^{\mathrm{d}}$ & $10.749 \pm 0.35^{\mathrm{d}}$ \\
GM & $9.343 \pm 0.22^{\mathrm{d}}$ & $19.630 \pm 0.66^{\mathrm{b}}$ & $23.704 \pm 0.99^{\mathrm{a}}$ \\
SBM & $4.917 \pm 0.27^{\mathrm{e}}$ & $7.231 \pm 0.62^{\mathrm{d}}$ & $9.280 \pm 1.81^{\mathrm{c}}$ \\
\hline
\end{tabular}

$\mathrm{CM}=$ Canola meal; $\mathrm{CSM}=$ Cotton seed meal; FM= Fish meal; $\mathrm{GM}=$ Guar meal; $\mathrm{SBM}=$ Soybean meal

lipase activity was observed in the whole intestine when fish were fed with GM diets while minimum activity was observed in anterior part of intestine for CM diets. Ma (2014) reported positive correlation between lipase activity and dietary lipid content in fish. The variation in feed composition causes changes in the specific activity of digestive enzymes in P. pagrus (Suzer et al., 2007). Ismat et al. (2013) observed highest lipase activity in Catla catla fed with SBM diets whereas Hypophthalmichthys molitrix showed poor performance. Fernandez et al. (2001) pointed out that digestive adaptation in different species exhibit closer correlation with their diet rather than on their taxonomic category. Similarly, Kuzmina (1996) also stated that changes in digestive enzyme activity could be affected by feeding behaviour and biochemical composition of feed.

In the present study, histological changes were also observed in the liver of fish fed with different feed ingredients. Severe vacuolation of hepatocytes and mild congestion were seen in sinusoids in fish liver fed with CM diet (Fig. 1). Robaina et al. (1995) observed hepatocytes vacuolisation and disorganisation in the liver of the fish fed on $30 \%$ SBM diet. Similarly, unstained portions showing fat vacuoles were observed in hepatocytes of fish fed with CSM diet (Fig. 2). Demska-Zakes et al. (2012) reported congestion, vacuolisation in hepatocytes, nuclear chromatin and nucleus disintegration when supplementary feed containing vegetable oil was offered to juvenile tench (Tinca tinca). Vacuolation in hepatocytes with pyknotic nuclei were observed in fish fed on FM diet

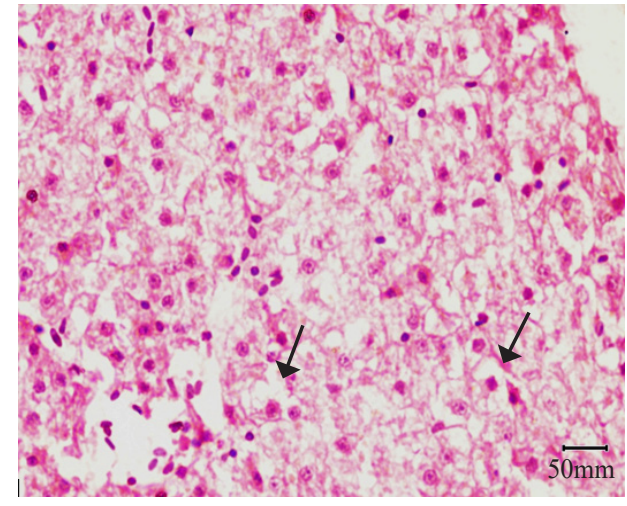

Fig. 1. Liver section of L. rohita fed CM diet showing severe vacuolation of hepatocytes $(\longrightarrow$ ) and mild congestion seen in sinusoids (H\&E; $\mathrm{x} 40$ ).

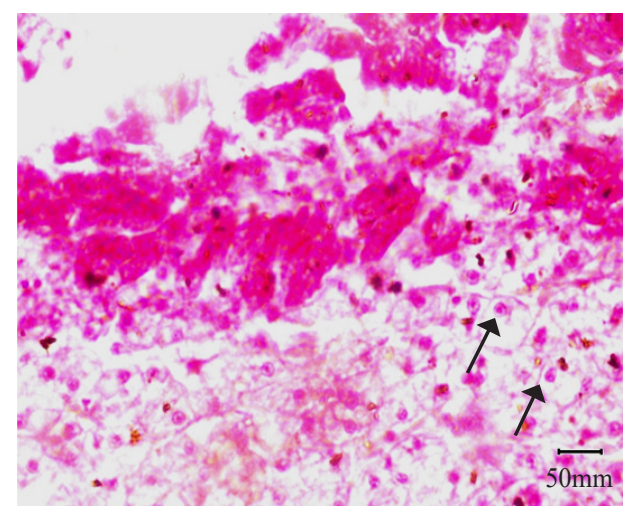

Fig. 2. Liver section of $L$. rohita fed CSM diet. Fat vacuolation evident in hepatocytes $(\longrightarrow)$ and mild congestion seen in sinusoids (H \& E; $\mathrm{x} 40)$ 
(Fig. 3). GM feed caused severe cytoplasmic vacuolation (Fig. 4) while SBM caused hepatocytes degeneration and mild vacuolation (Fig. 5). Bac et al. (1983) and Parpoura and Alexis (2001) observed necrosis and degeneration of hepatocytes cell membranes in European seabass and gilthead seabream (Sparus aurata L.) receiving feeds supplemented with soy oil. Similarly, common carp fed with $50 \%$ mustard protein showed histological abnormalities in liver tissues (Hossain and Jaunecy, 1989).

Several researchers have observed changes in intestine of fish fed with plant origin feed which suppressed fish growth (Van den Ingh et al., 1991; Baeverfjord and Krogdahl, 1996; Refstie et al., 2000; Krogdahl et al., 2003; Knudsen et al., 2008). During the present study mild infiltration of leucocytes in lamina propria and in lumen as well as sloughed tissue debris was seen in mid intestine of $L$. rohita fed with GM diet (Fig. 6). Similarly, SBM diet caused degenerative changes on surface epithelial cells (Fig. 7). In common carp

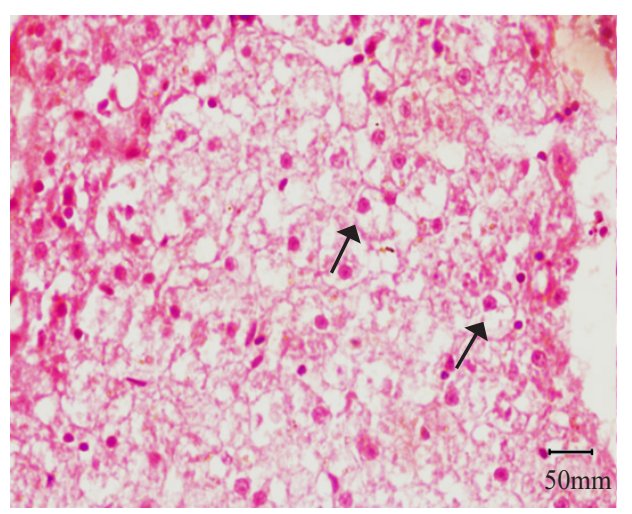

Fig. 3. Liver section of L. rohita fed on FM diet. Vacuolation $(\longrightarrow)$ seen in hepatocytes with pyknotic nuclei (H\&E; x40).

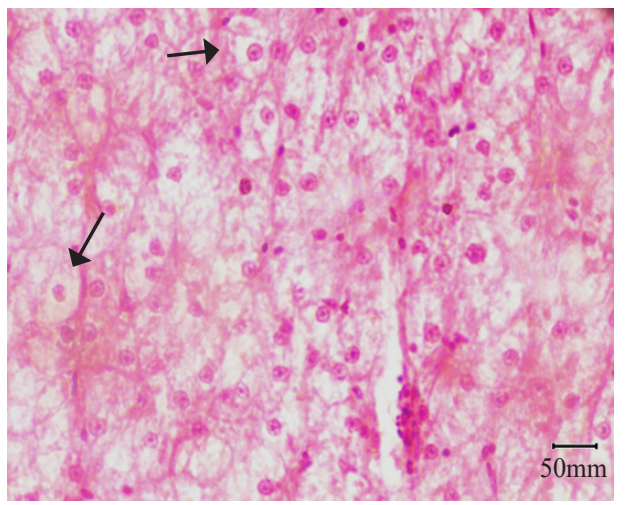

Fig. 4. Liver section of L. rohita fed with GM diet showing severe cytoplasmic vacuolation $(\longrightarrow)(\mathrm{H} \& \mathrm{E} ; \mathrm{x} 40)$.

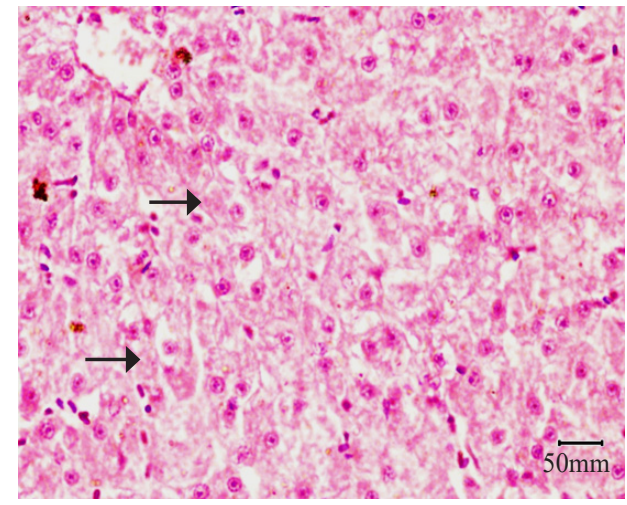

Fig. 5. Liver section of L. rohita fed SBM diet showing hepatocyte degeneration and mild vacuolation (H\&E; x40).

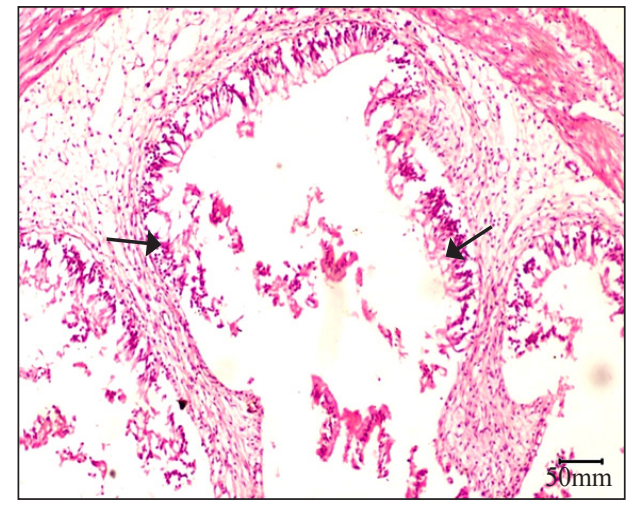

Fig. 6. Histological section of mid intestine of $L$. rohita fed on GM diet. Mild infiltration of leucocytes seen in lamina propria of intestine and in the lumen sloughed tissue debris also seen (H\&E; $x 40)$.

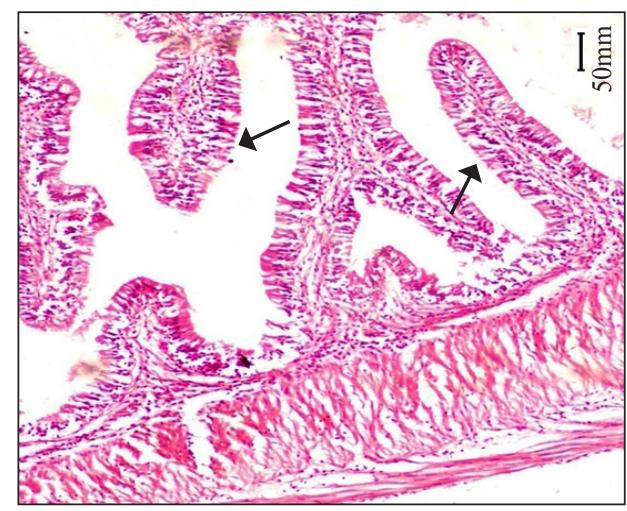

Fig. 7. Mid intestine of $L$. rohita fed on SBM diet showing degenerative changes $(\longrightarrow$ ) on surface epithelial cells (H\&E; $\mathrm{x} 40)$

(Cyprinus carpio), signs of enteritis were observed when fed with high levels of SBM (Uran et al., 2008) while Bonaldo et al. (2006) observed no pathological changes in intestines of Solea aegyptiaca when 30\% FM was 
replaced with SBM. FM diet caused detachment of surface epithelial cells from underlying lamina propria indicating necrotic changes (Fig. 8). Kumar et al. (2010) observed necrosis of enterocytes and denudations of the upper laminar epithelium, accompanied by a massive influx of leucocytes into the lamina propria of the villi when $75 \%$ of FM protein was replaced by detoxified Jatropha kernel meal. CSM diet resulted in neutrophillic infiltarion in lamina propria with segmented nucleus and there was also goblet cell hyperplasia in mucosa (Fig. 9). Edematous fluid along with leucocytic infiltration in the lamina propria and small blood vessels were observed in intestine when L. rohta was fed with CM diet (Fig. 10). Markovic et al. (2012) observed increased leucocytes infiltration in the epithelium often accompanied by increased mucous production when carp was fed with plant origin feed. Baeverfjord and Krogdahl (1996) and Uran et al. (2008)

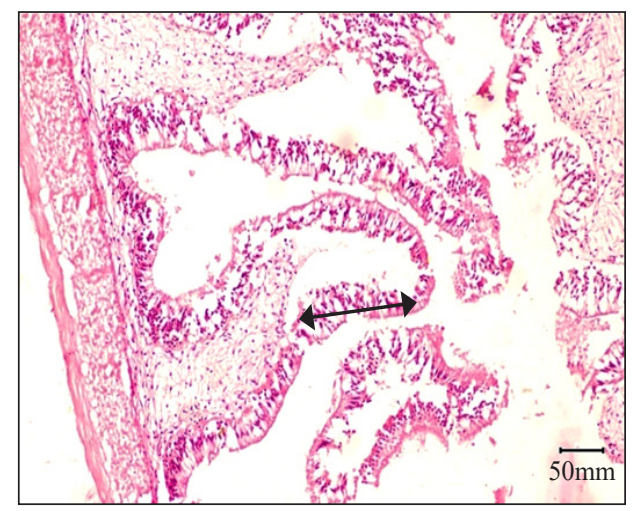

Fig. 8. Mid intestine of L. rohita fed on FM diet showing detachment of surface epithelial cells from underlying lamina propria indicating necrotic changes $(\longmapsto$, $\mathrm{H} \& \mathrm{E} ; \mathrm{X} 40)$

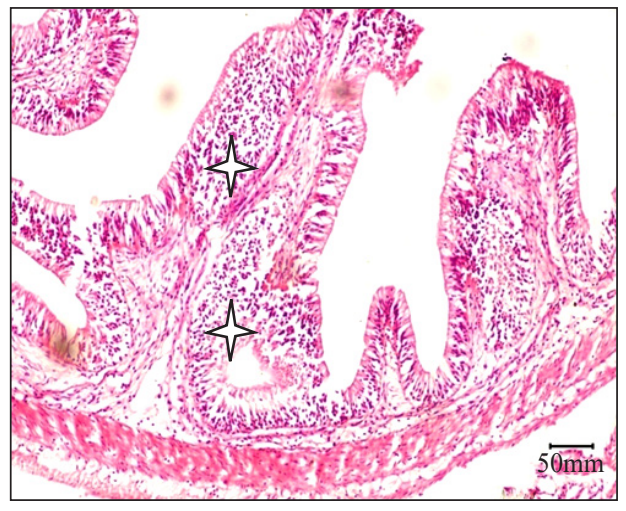

Fig. 9. Mid intestine of $L$. rohita fed on CSM diet showing neutrophillic infiltarion $(\$)$ in lamina propria with segmented nucleus. Goblet cell hyperplasia in mucosa (possible) is also seen

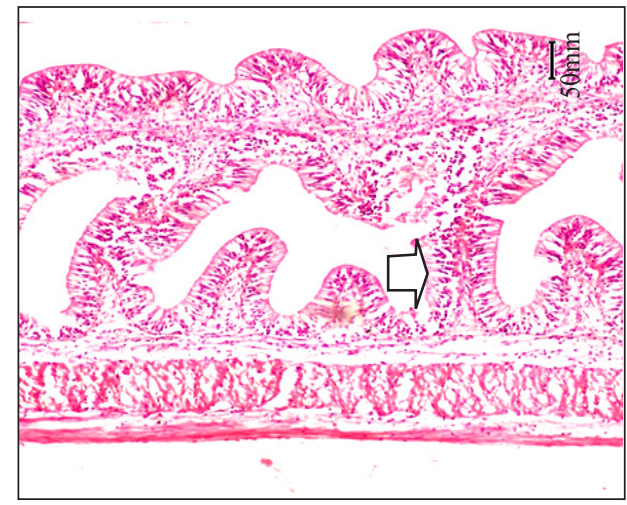

Fig. 10. Mid intestine of $L$. rohita fed on CM diet showing presence of edematous fluid along with leucocytic infiltration $(\square)$ in the lamina propria. Small blood vessels are engorged (H\&E;X40)

reported enteritis which involved inflammatory infiltrate in fish intestine fed with soybean meal.

Based on the results of the present study, it can be concluded that every ingredient behaves differently in the intestine due to differences in nature of nutrients. Better protease level was observed in the whole intestine when fish were fed with CSM and FM which ultimately enhanced fish growth.

\section{References}

Abid, M. and Ahmed, M. S. 2009. Growth response of Labeo rohita fingerlings fed with different feeding regimes under intensive rearing. J. Anim. Plant Sci., 19(1): 45-49.

Ali, M., Salam, A., Azeem, A., Shafiq, M. and Khan, B. A. 2000. Studies on the effect of seasonal variations on physical and chemical characteristics of mixed water from river Ravi and Chenab at union site in Pakistan. J. Res. Sci., 11: 11-17.

Aliyu-Paiko, M., Hashim, R. and Shu-Chien, A. C. 2010. Influence of dietary lipid/protein ratio on survival, growth, body indices and digestive lipase activity in snakehead (Channa striatus, Bloch 1793) fry reared in recirculating water system. Aquac. Nutr., 16(5): 466-474. doi.org/10.11 11/j.1365-2095.2009.00683.x.

APHA 1998. Standard methods for the examination of water and wastewater, $20^{\text {th }}$ edn. American Public Health Association, American Water Works Association and the Water Environment Federation, USA, 1220 pp.

Bac, N., Biagianti, S. and Brusle, J. 1983. Etude cytologique ultrastructurale des anomalies hepatiques du Loup, de la Daurade et de I'Anguille, induites par une ali-mentation artificielle. Bases biologiques de l' aquaculture. In: Actes de Colloque, No. 1. Ifremer, Montpellier, France, p. 473-484. 
Baeverfjord, G. and Krogdahl, A. 1996. Development and regression of soybean meal induced enteritis in Atlantic salmon (Salmo salar L) distal intestine: a comparison with the intestines of fasted fish. J. Fish Dis., 19: 375-387. doi.org/10.1046/j.1365-2761.1996.d01-92.x.

Bonaldo, A., Roem, A., Pecchini, A., Grilli, E. and Gatta, P. 2006. Influence of dietary soybean meal levels on growth, feed utilisation and gut histology of Egyptian sole (Solea aegyptiaca) juveniles. Aquaculture, 261: 580-586. doi.org/ 10.1016/j.aquaculture.2006.08.013.

Buchet, V., Infante, J. L. Z., Cahu, C. L. 2000. Effect of lipid level in a compound diet on the development of red drum (Sciaenops ocellatus) larvae. Aquaculture, 184: 339-347. doi.org/10.1016/S0044-8486(99)00325-7.

Caballero, M. J., Izquierdo, M. S., Kjorsvik, E., Fernandez, A. J. and Rosenlund, G. 2004. Histological alterations in the liver of sea bream, Sparus aurata, caused by short or long-term feeding with vegetable oils. Recovery of normal morphology after feeding fish oil as the sole lipid source. J. Fish Dis., 27: 531-541. DOI: 10.1111/j.1365-2761. 2004.00572.x.

Delgado, C. L., Rosegrant, M. W., Wada, N., Meijer, S. and Ahmed, M. 2002. Fish as food: Projections to 2020 under different scenarios. Markets and Structural Studies Division, International Food Policy Research Institute, Washington, D. C. http:www.ifpri.org/divs/mtid/dp/papers /mssdp52.pdf. (Accessed 24 November 2015).

Demska-Zakes, K., Zakes, Z., Ziomek, E. and Jarmolowicz, S. 2012. Impact of feeding juvenile tench Tinca tinca (L.), feeds supplemented with vegetable oils on hematological indexes and liver histology. Arch. Pol. Fish., 20: 67-75. DOI 10.2478/v10086-012-0009-z.

El-Sayed, A. F. M., Martinez, I. M and Moyano, F. M. 2000. Assessment of the effect of plant inhibitors on digestive proteases of Nile tilapia using in vitro assays. Aquac. Int., 8: 403-415.

Eroldogan, O. T., Kumlu, M. and Aktas, M. 2004. Optimum feeding rate for European seabass Dicentrarchus labrax reared in seawater and freshwater. Aquaculture, 231(1-4): 501-515. doi.org/10.1016/j.aquaculture.2003.10.020.

Eroldogan, O. T., Kumlu, M. and Sezer, B. 2006a. Effects of starvation and re-alimentation periods on growth performance and hyperphagic response of Sparus aurata. Aquac. Res., 37(5): 535-537. DOI: 10.1111/j.1365-2109. 2006.01445.x.

Eroldogan, O. T., Kumlu, M., Kiris, G. A. and Sezer, B. 2006 b. Compensatory growth response of Sparus aurata following different starvation and refeeding protocols. Aquac. Nutr., 12: 203-210. doi.org/10.1111/j.1365-2095.2006.00402.x.

Eusebio, P. S. and Coloso, R. M. 2002. Proteolytic enzyme activity of juvenile Asian seabass, Lates calcarifer (Bloch), is increased with protein intake. Aquac. Res., 33: 569-574.
Fernandez, I., Moyano, F. J., Diaz, M. and Martınez, T. 2001. Characterisation of $\alpha$-amylase activity in five species of Mediterranean sparid fishes (Sparidae, Teleostei). J. Exp. Mar. Biol. Ecol., 262: 1-12. DOI: 10.1016/S0022-0981 (01)00228-3.

Francis, G., Makkar, H. P. S. and Becker, K. 2001. Antinutritional factors present in plant-derived alternate fish feed ingredients and their effects in fish. Aquaculture, 199: 197-227. doi.org/10.1016/S0044-8486(01)00526-9.

Gomez-Requeni,P.,Mingarro,M.,Calduch-Giner,J.A.,Medale,F., Martin, S. A. M., Houlihan, D. F., Kaushik, S. and PerezSanchez, J. 2004. Protein growth performance, amino acid utilisation and somatotropic axis responsiveness to fish meal replacement by plant protein sources in gilthead seabream (Sparus aurata). Aquaculture, 232: 493-510. doi. org/10.1016/S0044-8486(03)00532-5.

Harms, J., Anger, K., Klaus, S. and Seeger, B. 1991. Nutritional effects on ingestion ate, digestive enzyme activity, growth and biochemical composition of Hyas araneus L. (Decapoda: Majidae) larvae. J. Exp. Mar. Biol. Ecol., 145: 233-265. doi.org/10.1016/0022-0981(91)90178-Y.

Hidalgo, M. C., Urea, E. and Sanz, A. 1999. Comparative study of digestive enzymes in fish with different nutritional habits, proteolytic and amylase activities. Aquaculture, 170: 267-283. doi.org/10.1016/S0044-8486(98)00413-X.

Hossain, M. A. and Jauncey, K. 1989. Nutritional evaluation of some Bangladeshi oil seed meals as partial substitutes for fishmeal in the diets of common carp, Cyprinus carpio L. Aquac. Fish. Manag., 20: 225-268. doi.org/10.1111/j. 1365-2109.1989.tb00351.x.

Humason, G. L. 1979. Animal tissue techniques, $4^{\text {th }}$ edn., Freeman, San Francisco.

Iqbal, K. J., Ashraf, M., Javid, A., Abbas, F., Hafeez-ur-Rehman, M., Rasool, F., Khan, N., Abbas, S. and Altaf, M. 2014. Effect of feed on the mineral composition of Labeo rohita. Intl. J. Farm Allied Sci., 3(9): 952-955.

Iqbal, K. J., Ashraf, M., Qureshi, N. A., Javid, A., Abbas, F., Hafeez-ur-Rehman, M., Rasool, F., Khan, N. and Abbas, S. 2015. Optimising growth potential of Labeo rohita fingerlings fed on different plant origin feeds. Pakistan J. Zool., 47(1): 31-36.

Ismat, N., Ashraf, M., Naeem, M. and Hafeez-ur-Rehman, M. 2013. Effect of different feed ingredients on growth and level of intestinal enzyme secretions in juvenile Labeo rohita, Catla catla, Cirrhinus mrigala and Hypophthalmicthys molitrix. Int. J. Aquac., 3: 85-91.

Johnston, D. J., Ritar, A. J. and Thomas, C. W. 2004. Digestive enzyme profile reveal digestive capacity and potential energy sources in fed and starved spiny lobster (Jasus edwardsii) phyllosoma larvae. Comp. Biochem. Physiol., 138(B): 137-144. DOI: 10.1016/j.cbpc.2004.02.013. 
Khan, M. A., Ahmed, I. and Abidi, S. F. 2004. Effect of ration size on growth, conversion efficiency and body composition of fingerling mrigal, Cirrhinus mrigala (Hamilton). Aquac. Nutr., 10: 47-53. doi.org/10.1046/ j.1365-2095.2003.00279.x.

Knudsen, D., Jutfelt, F., Sundh, H., Sundell, K., Koppe, W. and Frokiær, H. 2008. Dietary soya saponins increase gut permeability and play a key role in the onset of soyabeaninduced enteritis in Atlantic salmon (Salmo salar L.). Brit. J. Nutr., 100: 120-129. doi: 10.1017/S0007114507886338. Epub 2008 Jan 2.

Kolkovski, S. 2001. Digestive enzymes in fish larvae and juveniles-implications and applications to formulated diets. Aquaculture, 200: 181-201. doi.org/10.1016/S00448486(01)00700-1.

Krogdahl, A., Bakke-McKellep, A. and Baeverfjord, G. 2003. Effects of graded levels of standard soybean meal on intestinal structure, mucosal enzyme activities and pancreatic response in Atlantic salmon (Salmo salar L.). Aquac. Nutr., 9: 361-371. doi.org/10.1046/j.13652095.2003.00264.x.

Kumar, R. V., Ramesh, K. S., Patil, P., Kumar, B. T. N. and Manissery, J. K. 2011. Dietary protein requirement of stunted fingerlings of rohu, Labeo rohita (Hamilton) during grow-out stage. Indian J. Fish., 58(4): 49-53.

Kumar, V., Harinder, P. S. M., Amselgruber, W. and Becker, K. 2010. Physiological, haematological and histopathological responses in common carp (Cyprinus carpio L.) fingerlings fed with differently detoxified Jatropha curcas kernel meal. Food Chem. Toxicol., 48: 2063-2072. doi: 10.1016/j. fct.2010.05.007.

Kuzmina, V. V. 1996. Digestive enzymes are indicators of feeding ecology of wild fish. In: MacKinlay, D. and Shearer, K. (Eds.), Proceedings of the symposium on feeding ecology and nutrition in fish. American Fisheries Society, Vancouver, p. 9-13.

Li, X., Jiang, Y., Liu, W. and Ge, X. 2012. Protein-sparing effect of dietary lipid in practical diets for blunt snout bream (Megalobrama amblycephala) fingerlings, effects on digestive and metabolic responses. Fish Physiol. Biochem., 38(2): 529-541. doi: 10.1007/s10695-011-9533-9.

Louka, N., Juhel, F., Fazilleau, V. and Loonis, P. 2004. A novel colorimetry analysis used to compare different drying fish processes. Food. Cont., 15: 327-334. doi.org/10.1016/ S0956-7135(02)00119-6.

Lundstedt, L. M., Melo, J. F. B., Neto, C. and Moraes, G. 2002. Diet influences proteolytic enzyme profile of the South American catfish Rhamdia quelen. In: Proceedings of the International Congress on the Biology of fish, biochemical and physiological advances in finfish aquaculture. Vancouver, Canada.

Ma, X., Hu, Y., Wang, X., Ai Q., He, Z., Feng, F. and Lu, X. 2014. Effects of practical dietary protein to lipid levels on growth, digestive enzyme activities and body composition of juvenile rice field eel (Monopterus albus). Aquac. Int., 22: $749-760$

Markovic, Z., Poleksic, V., Lakic, N., Zivic, I., Dulic, Z., Stankovic, M., Spasic, M., Raskovic, B. and Sorensen, M. 2012. Evaluation of growth and histology of liver and intestine in juvenile carp (Cyprinus carpio, L.) fed extruded diets with or without fish meal. Turk. J. Fish. Aquat. Sci., 12: 301-308. DOI: 10.4194/1303-2712-v12_2_15.

Martinez, S., Navalon, J. L., Ortiz, A., Montalvo, G., Ferrero, J. L. and Gonzalez, A. 2003. The use of NIRS to predict chemical composition of ungrounded poultry feeds. $14^{\text {th }}$ European Symposium on Poultry Nutrition, August, 2003, Lillehammer, Norway, p. 91-92.

Parpoura, A. C. R. and Alexis, M. N. 2001. Effect of different dietary oils in sea bass (Dicentrarchus labrax) nutrition. Aquac. Int., 9: 463-476. DOI: 10.1023/A:1020590701325.

Poleksic, V., Raskovic, B., Markovic, Z., Dulic, Z., Stankovic, M., Zivic, I. and Lakic, N. 2007. Effects of different dietary protein sources on intestine and liver morphology of carp yearlings. Proceedings of the $3^{\text {rd }}$ Serbian Congress for microscopy. Serbian Microscopy Society, Belgrade, Serbia, p. 237-238.

Refstie, S., Korsoen, O.J., Storebakken, T., Baeverfjord, G., Lein,I. and Roem, A. J. 2000. Differing nutritional responses to dietary soybean meal in rainbow trout (Oncorhynchus mykiss) and Atlantic salmon (Salmo salar). Aquaculture, 190: 49-63. doi.org/10.1016/S0044-8486(00)00382-3.

Robaina, L., Izquierdo, M. S., Moyano, F. J., Socorro, J., Vergara, J. M., Montero, D. and Fernandez-Palacios, H. 1995. Soybean and lupin seed meals as protein sources in diets for gilhead seabream (Sparus aurata): Nutritional and histological implication. Aquaculture, 130: 219-233. doi. org/10.1016/0044-8486(94)00225-D.

Rodiles, A., Santigosa, E., Herrera, M., Hachero-Cruzado, I., Cordero, M. L., Martınez-Llorens, S., Lall, S. P. and Alarcon, F. J. 2012. Effect of dietary protein level and source on digestive proteolytic enzyme activity in juvenile Senegalese sole, Solea senegalensis Kaup 1850. Aquac. Int., DOI: 10.1007/s10499-012-9508-6.

Romarheim, O. H., Skrede, A., Penn, M., Mydlanda, L. T., Krogdahl, A. and Storebakken, T. 2007. Lipid digestibility, bile drainage and development of morphological intestinal changes in rainbow trout (Oncorhynchus mykiss) fed diets containing defatted soybean meal. Aquaculture, 274: 329-338. DOI: 10.1016/j.aquaculture.2007.11.035.

Santigosa, E., Sa'nchez, J., Me'dale, F., Pe'rez-Sa 'nchez, J. and Gallardo, M. A. 2008. Modifications of digestive enzymes in trout (Onchorynchus mykiss) and sea bream (Sparus aurata) in response to dietary fish meal replacement by plant protein sources. Aquaculture, 252: 68-74. 
Sethuramalingam, T. A. and Haniffa, M. A. 2002. Effect of formulated diet on digestive enzymes of Labeo rohita (Ham.). Indian J. Exp. Biol., 40(1): 83-88.

Smith, L. S. 1980. Digestion in teleost fish. In: Lectures presented at the FAO/UNPD training course in fish feed technology. $A D C P / R E P / 80 / 11$, p. 3-17.

Sunde, J., Eiane, S. A., Rustad, A., Jensen, H. B., Opstvedt, J., Nygard, E., Venturini, G. and Rungruangsak-Torrissen, K. 2004. Effect of fish feed processing conditions on digestive protease activities, free amino acid pools, feed conversion efficiency and growth in Atlantic salmon (Salmo salar L.). Aquac. Nutr., 10: 261-277. doi.org/10.1111/j.13652095.2004.00300.x

Suzer, C., Kamaci, H. O., Coban, D., Saka, S., Firat, K., Ozkara, B. and Ozkara, A. 2007. Digestive enzyme activity of the red porgy (Pagrus pagrus, L.) during larval development under culture conditions. Aquac. Res., 38: 1778-1785. DOI: $10.1111 / \mathrm{j} .1365-2109.2007 .01841 . \mathrm{x}$
Uran, P. A., Goncalves, A. A., Taverne-Thielem, J. J., Schrama, J. W., Verreth, J. A. J. and Rombout, J. H. W. M. 2008. Soybean meal induces intestinal inflammation in common carp (Cyprinus carpio L.). Fish Shellfish Immunol., 25: 751-760. doi: 10.1016/j.fsi.2008.02.013. Epub 2008 Mar 4.

Uran, P. A., Schrama, J. W., Jaafari, S., Baardsen, G., Rombout, J. H. W. M., Koppe, W. and Verreth, J. A. J., 2009. Variation in commercial sources of soybean meal influences the severity of enteritis in Atlantic salmon (Salmo salar L.) Aquac. Nutr., 15: 492-499. doi.org/10.1111/j.1365-2095. 2008.00615.x.

Van Den Ingh, T. S. G. A., Krogdahl, A., Olli, J. J., Hendriks, H. G. C. J. and Koninkx, J. G. J. F. 1991. Effects of soybeancontaining diets on the proximal and distal intestine in Atlantic salmon (Salmo-Salar): a morphological study. Aquaculture, 94: 297-305. doi.org/10.1016/00448486(91)90174-6. 